\title{
Ethical food as a differentiation factor for tourist destinations: The case of "Slow Food"
}

\author{
Milena Viassone ${ }^{1, \text { * }}$, Martin Grimmer ${ }^{2}$ \\ ${ }^{1}$ Department of Management, University of Turin, Turin, Italy \\ ${ }^{2}$ Tasmanian School of Business and Economics, University of Tasmania, Hobart, Australia
}

\section{Email address:}

milena.viassone@unito.it (M. Viassone),martin.grimmer@utas.edu.au (M. Grimmer)

\section{To cite this article:}

Milena Viassone, Martin Grimmer. Ethical Food as a Differentiation Factor for Tourist Destinations: The Case of "Slow Food". Journal of Investment and Management. Special Issue: Attractiveness and Governance of Tourist Destinations. Vol. 4, No. 1-1, 2015 , pp. 1-9. doi: $10.11648 /$ j.jim.s.2015040101.11

\begin{abstract}
In recent years, the topic of ethical food has assumed increasing importance in international academic debate. Despite there being some studies carried out on this topic, there is limited literature on the role ethical food plays in the tourism sector and, specifically, in tourist destination attractiveness. This paper explores how ethical food can be a driver of destination attractiveness and how it is possible to take advantage of this issue for particular tourist destinations. In this paper, ethical food as a destination attraction is explained through the case of Slow Food. Results show that ethical food has a very important role to play in the future of destination attractiveness thanks to special events and projects concerning ethical food, which also contribute to the sustainability of a destination. Finally, strategies to exploit the potential of this ethical food so as to develop tourist destination attractiveness are drawn.
\end{abstract}

Keywords: Ethical Food, Tourist Destination, Slow Food, Tourist Strategies, Sustainability

\section{Introduction}

The theme of ethical food has received increasing attention in recent years and it is more and more at the center of the international economic debate. At the same time, food tourism has grown considerably, becoming one of the most dynamic and creative segments of tourism. Food is considered an important factor to diversify tourism and to stimulate tourist destination development. However, food tourism must also consider ethical and sustainability values based on the culture and specific local products of the regions in question [1].

Consumers in general understand that ethical food choices are good not just for society, but for themselves and their families [2]. The growing awareness of consumers has provoked an increase of the demand for ethical foods, resulting in demand in the organic and fair-trade market. In particular, the sector is estimated to account $5 \%-10 \%$ of the total food and beverage trade globally [3]. The UK, Western Europe, the USA and Canada have dominated the ethical food market for the last decade, accounting for $97 \%$ of organic and fair-trade sales. In emerging markets such as India and China, the growth of ethical food and drink sales is predicted to increase in the next few years [4].
This growth in interest in ethical food also positively affects ethical tourism and ethical tourism products. Indeed, the behavior of tourists has changed such that they often opt for new kinds of destinations with food and beverages playing an important role in tourist attractiveness. In this way, food and drink are now considered part of the character and culture of a destination [5]. This is particularly important in the Italian context where food plays a significant role in attracting tourists.

While the topic of ethical food has attracted interest in and of itself, there is a lack of work on the role it plays in the tourism industry. This paper aims at emphasizing how ethical food can be a driver of destination attractiveness and how it is possible to take advantage of this issue for particular tourist destinations. To achieve this objective, an example of how ethical food results in attracting tourists to specific regions is offered through the case of Slow Food. This paper provides the first examination of literature on supply and consumption barriers regarding ethical food and its link with the tourism industry. Slow Food, as the exemplar case of the tourism link, is one of the most famous ethical food organizations in the 
world. Its origin, projects and events which attract tourists are analyzed using existing Slow Food documents, relevant databases and extant literature on the organization. Finally, several strategies are proposed for the exploitation of ethical food for the development of tourist destination attractiveness.

\section{Literature Review}

\subsection{Ethical Food: Supply and Consumption}

The importance of the food industry has increased in different economies around the world. Food distribution is about more than moving products from one place to another; lifestyles, diets and health are of course influenced by the rise of the ready meal, the pre-packed sandwich and the exotic fruits that the chill-chain makes possible [6]. In a 2006 speech, the European Commissioner for Agriculture, Marian Fischer Boel, suggested that ethical foods could play a significant role in re-orienting Europe's food system for the 21st century [7]. Consumers are more and more aware of their consumption choices and their impact, and this awareness is particularly seen in food consumption where ethical considerations apply to product, brand and channel choices [8] [9].

On the demand side, ethical stances are able to shift consumers away from specific market offerings and moderate behaviors to be more responsive to ethical requirements [8]. Ethical consumption does not have a shared definition. Muncy and Vitell [10] consider it as "the moral principles and standards that guide [the] behavior of individuals or groups as they obtain, use and dispose of goods and services". For Crane and Matten [11], the main essence of this concept is "the conscious and deliberate decision to make certain consumption choices due to personal moral beliefs and values". Discussion on ethical food and green consumption investigates whether or not people have a moral obligation to act ethically in order to achieve sustainable development or are individually overburdened by taking on a responsibility they cannot shoulder [12]. Szmigin and Carrigan [13] conceptualize ethical consumption by positioning it within Holt's (1995) typology of consumption practices. Holt analyzes ethical consumption as an integration process, that is, the "methods used by consumers to enhance perception that a valued consumption object is a constitutive element of their identity" [14]. He identifies four possible dimensions of ethical consumption: as a distinction process, as hedonistic pleasure, as a sign of love and as engaging an aesthetic response.

On the supply side, firms are engaging more and more in Corporate Social Responsibility (CSR) activities and making efforts to communicate their CSR purposes $[15,16]$. The ethical food sector currently accounts for $5 \%-10 \%$ of the total food and beverage market, and there is an awareness that agriculture's future objective consists of feeding the globe in volume and quality terms but doing so on a sustainable basis [17]. It is important here to distinguish the different responsibilities of companies versus government: the first are responsible for food organizing and production while the second for the grant of safety of the food and for fair access to food supply for everyone. Various supply sources of ethical food and their related capacity are discussed as follows.

Many firms have developed an offer of organic and natural food without genetic modification, that is, without the use of chemical pesticides, artificial fertilizers or sewage sludge with reference to crops; or with reference to animals, raised without use of antibiotics or hormones. In 2009, the number of organic producers worldwide was 1.8 million, with $40 \%$ in Asia, $28 \%$ in Africa and $16 \%$ in Latin America [18]. The UK, Western Europe, the US and Canada have meaningful domestic supply bases of organic food, and Australia and New Zealand have substantial production, Yet, there is a worldwide undersupply of organic produce, particularly with reference to fruit and vegetables, meat and dairy [4]. Local organic food supply chains are complex and mainly composed of SMEs that are engaged in shortening the distances between themselves and the final customers. These producers often sell their products through alternative food purchasing venues (e.g., farmers' markets) [19]. These types of products have developed more and more in the food and beverage sector in response to the increasing needs of customers to know more information on the sources and operations related to their products.

An example of this particular model is offered by Starbucks which buy fair-trade certified coffee from importers who have purchased it from farmers for a price higher than that of the market [20]. Fair-trade in 2009 counted 827 producer organizations spread over 60 countries. Increases have been registered in fair-trade sugar, fruit juices, herbs and spices. In particular, in 2009, bananas fair-trade sales volume rose by 311,465 metric tonnes, coffee by 73,781 , fruit juices by 45,582 , fresh fruit by 20,091 , cocoa by 13,898 , wine by 11,908 , tea by 11,524 , rice by 5,052 , honey by 2,065 , nuts and oilseeds by 859 , herbs and spices by 578, dried fruit by 541 [4]. But in this case, fair-trade product supply is higher than demand, by a considerable margin.

Free Range (i.e., animals raised for consumption living a more natural life) and Animal Welfare Friendly labelling have also become more prominent. Starting in the 1970's, agricultural animal production has been affected by several changes, showing a higher level of specialization of farms, a high number of animals per farm and an increase in mechanization, all resulting in more industrialized animal production. This often meant focusing price, supply and competition more on quantity than on quality, which has also affected perceptions of animal farm production and conditions [21].

In conjunction, the topic of animal welfare increased in importance in the economic debate, especially after swine fever and avian influenza. Methods identified by Welfare Quality to improve animal welfare in Europe consist of defining innovative, knowledge-based, practical species-specific strategies that can be applied directly on the farm or in primary production (i.e., breeding companies). The development of a standardized welfare monitoring system and improved EU regulations concerning animal welfare (ensuring better conditions of housing, transport, etc) have 
also been mooted, in addition to making animal husbandry practices more transparent thus allowing consumers to be more informed in their purchases. [22].

Ethical food has also been associated with environmentally responsible and sustainable production systems. The main elements of the sustainability of ethical food concern sustainable production (the creation of goods/services using economically, safe and non-polluting processes, being able to conserve energy and natural resources, and providing socially rewarding for the working people). Local production is also favored (due to freshness of the produce, its nutritional content, and the lower carbon emissions as a result of reduced transport miles), as well as seasonality (seasonal food also generally doesn't travel great distances). Waste reduction and reduced packaging similarly are advantages of ethical food (e.g., purchasing loose fruits and vegetables, avoiding small bottles, purchasing only what is necessary) [4].

As a consequence of the importance of these aspects of ethical food, there is increasing international economic debate on the impact of different food product styles (e.g., fast versus slow food, international cuisine, health food). Of particular interest is the relationship between consumers, supply chains and the state. This relationship invokes more than just branding [23, 24] in that ethical food is supported by state-sanctioned certification systems, resulting in important social relationships between customers and food [25]. Generally speaking, demand and supply of ethical food interact dialectically, and there is a tension that exists between ethical stances that occur on the demand side and corporate initiatives for market growth that occur on the supply side. An exception is represented by the case of "Eataly" - the Italian food emporium founded in Torino - which is based on a collaboration between a private company and the Slow Food social movement with the purpose of creating a new business model. In this particular case, customers purchase Eataly's products while Slow Food acts as supporter of the initiative [8] Another well-known model is Infinity Foods, a workers' co-operative that produces only organic, fair-trade, vegetarian and locally grown products, owned and managed entirely by its staff of nearly 100 people. It operates like a normal place of business but distinguishes itself by its selection of fair-trade and organic herbal teas available on its warehousemen's tea trolley [26].

With reference to the supply channel, in Western Europe, retail sales of food represents about 80 per cent of total food sales. This includes two different circuits:

1. Modern retailing, representing approximately $70 \%$ of total food and drinks sales in Western Europe and constituted by supermarkets and hypermarkets mainly operating in groupings of various types, and

2. Secondary retailing, covering approximately $30 \%$ of total food and drinks sales in Western Europe and consisting of traditional independent grocers, specialists (i.e., bakers, fishmongers, greengrocers,), CTN (confectionery, tobacconists, newsagents, with some food sales), petrol filling stations with specialist shops and kiosks, drinks stores, convenience stores, and so forth [17].
Notwithstanding the general interest in ethical food, as stated earlier, it constitutes only $5-10 \%$ of the total food and beverage market and there are limited ethical food alternatives In many cases it is expensive and consumption is affected by availability and price $[27,28]$.

\subsection{Ethical Food as a Driver of Tourist Destination Attractiveness}

According to Sánchez Taylor [29] tourism is considered to be potentially exploitative and capable of perpetuating inequity and exclusion [30-32]. Indeed, while tourism is driver of growth of tourist destinations, it can provoke damaging effects associated with mass tourism (e.g., due to increased traffic, crowds, urban sprawl) [33, 34]. Thus, the sustainability of some tourist destinations can be compromised. In contrast, there is a trend that pushes tourism towards ethical behaviors: terms such as sustainable tourism, eco-tourism, and ethical tourism are more and more diffused in the literature [35].

The increasing number of tourists underlines the need for an ethical approach to travel and tourism. This point is also relevant with regard to food when it is considered as a "cultural product" [36]. There are important links between food and tourism and in the use of food as an expression of identity and culture [1]. Food can be "used as a means of differentiation for a destination in an increasingly competitive global marketplace" [37]. The promotion of traditional cuisine evokes nostalgia for "dishes of the past" and differentiates a destination from others, as is the case with Eataly in Torino. According to Vengesayi [38], an important driver of destination attractiveness concerns support facilities such as transport, accommodation, health and shopping, and food. Trunfio et al. [39] emphasize the increasing role of food tourism in the immersion of tourists in the culture of the destination [40].

Tourists look for concrete learning experiences, and in this field, gastronomic experience plays an increasingly prominent part. Hall and Sharples [41] consider food tourism as an experiential trip to a gastronomic destination, related to a particular lifestyle that includes experimentation, learning from other cultures, and the acquisition of knowledge about the characteristics of specific tourism products. These experiences constitute the main motivations that push tourists towards gastronomic destinations [1] and thus food becomes a real driver of destination attractiveness.

Wine and food tourism is a niche area of tourism studies that has grown rapidly in recent years [42]. Food tourism must include in its discourse ethical and sustainability values based on the territory, the landscape, the local culture and its products. As supported by FAO [43], a more equitable, ethically-based food and agriculture system must incorporate concern for three widely accepted global goals: improved well-being, protection of the environment and improved public health. In addition, biological efficiency and agro-biological diversity must be reconciled with economic efficiency. This means allowing the production of goods with fewer resources and limiting the pressure on the environment.

Research carried out by Birch [42] shows how consumers 
consider ethics as important in making buying decisions, and that buying local ethical foods results in stronger attachment to a local region. In this way, ethical identity can be a driver of the consumption of local food and beverages [43], and can be encouraged by the adoption of promotional messages and labeling by a particular destination [44]. Indeed, given that cuisine and culture affects tourist decisions, producers and associations of ethical food can link with tourism providers to develop tourist attractiveness around existing agricultural products in a region [46] [47]. In this regard, ethical food satisfies both the need for sustainability and for the differentiation of a destination.

\subsection{Barriers from the Supply and the Demand Side}

Despite efforts by government and business for the improvement of food distribution, and accepting the demand from consumers, sustainable development goals in food production still seem far away. Ethical food is affected by several barriers in terms of supply:

- the inability of government and business initiatives to promote sustainable food distribution as a response to geopolitical and cultural change [6];

- the high level of vulnerability to various kinds of contamination in supply chains due to longer connections and rapid fragmentation of ingredient sourcing (e.g., herbs from Kenya, conservation packages from Canada, soy sauce from India) [48];

- poor collaboration and information sharing among local organic food supply chain partners [49] that make their supply chains complex to design and manage;

- the limited availability of ethical products in supermarkets: the problem of "food miles" and the complicated logistics required to provide a wide choice to consumers in developed countries [50];

- rapid progress in the technologies applied to food production and conservation [25] that results in insufficient information to consumers;

- lack of knowledge of these products by consumers;

- high costs due to various factors including higher animal welfare standards and the internalization of costs normally externalized by conventional foods [51], and

- the "productionist paradigm" applied to food production practices during the last sixty years which actively militates against the producer taking heed of ethical concerns [52].

Żakowska-Biemans [53], referring to a specific country (Poland), argues that the main barriers to the consumption of ethical food from the demand side are: a lack of information and its absence in local or most frequently visited shops, limited availability, high prices, and the lack of confidence in the reliability of information on organic products. The Queensland Government in Australia [44] considers the main barriers to the consumption of ethical food to be: inadequate marketing and distribution with products not clearly branded; the perception that this type of food is expansive, and the inconvenience of these products. The same barriers are provided by Young et al. [54] who add also lack of time for research, decision-making and purchasing by the consumer. Other miscellaneous barriers include brand loyalty, culture, demographic and personality characteristics, habit, lifestyle, and the trading off between different ethical issues [55].

As ethical food can constitute an important driver for tourist destination attractiveness, it is necessary to develop strategies to overcome these constraints.

\section{The Impact of Ethical Food on Tourist Attractiveness: the Slow Food Movement}

\subsection{The Origin and Principles of Slow Food}

One of the most well-known ethical food organizations in the world is Slow Food. Now a global phenomenon, Slow Food was born from the passion for food (and politics) by the inhabitants of a small town in Italy (Bra) [56] as a type of opposition to fast food culture and also to establish a relationship between nature, pleasure and tradition. Slow Food had its genesis in the creation in 1986 of the association called "Arcigola" which formed in reaction to the methanol crisis of that year and the perceived diffusion of fast foods in Italy. Its main promoter, the journalist Carlo Petrini, wanted to advance Italian quality wines and local simple dishes which he saw as being under threat. Petrini created two important food guides: "Osterie d'Italia" and "Vini d'Italia". The Slow Food organization was officially created in Paris in 1989.

The Slow Food philosophy is encapsulated in the words "good, clean, fair" - "good" because food must stimulate the pleasure of eating; "clean" because food must be produced respecting the environment, animal welfare and people's heath, and "fair" because farmers, dealers and craftsmen must be adequately paid [57]. In this regard, Slow Food advocates the payment of the "right" price to a producer so as to reduce the risk of exploitation and increase the chance of food/product preservation. The Slow Food Manifesto states:

"We are enslaved by speed and have all succumbed to the same insidious virus: Fast Life, which disrupts our habits, pervades the privacy of our homes and forces us to eat Fast Foods. In the name of productivity, Fast Life has changed our way of being and threatens our environment and our landscapes. So Slow Food is now the only truly progressive answer".

Today, Slow Food has over 100,000 members joined in 1,500 "Convivia" or chapters, as well as a network of 2,000 food communities who practice small-scale and sustainable production of quality foods (Slow Food International Website). Slow Food is articulated in four different administrative units: Arcigola Slow Food Promotion Srl, responsible for the big initiatives, such as "Salone del Gusto"; Arcigola Slow Food Editore Srl, in charge of the editorial program of the association; Arcigola Slow Food Association, in charge of recruitment and associates activities in Italy, and Slow Food International, in charge of recruitment and associated activities abroad [58]. 


\subsection{How Slow Food Attract Tourist through Ethical Food: Results and Discussion}

Given that tourism is an important economic activity in Italy, it is important that traditional tourist activities - and in particular those focused on food tourism - develop the sensitivity to protect and integrate with the natural and cultural resources available in a particular region [59].

Slow food tourism can be considered as an important part of the cultural tourism market, attracting tourists who seek unique experiences and the consumption of local food and beverages. For this same reason several rural communities use food festivals and farmers' markets to promote local products, thus enhancing the image of the destination [60].

Using the principles mentioned in the previous subsection as a basis, many food tourism oriented practical projects have been developed by Slow Food:

- Taste education, organized in order to educate consumers to recognize and appreciate seasonal foods. In order to achieve these results several initiatives are organized by Slow Food: the "Salone del Gusto", an event which began in 1996 and organized every two years in Turin, where producers and farmers from around the world showcase their products; courses and workshops organized by Slow Food, and the creation of the first "Università del Gusto" in Pollenzo (close to Bra), and in Colorno (close to Parma) that brings together experts and promoters of food from around the world.

- Foundation Slow Food, created to promote biodiversity and preserve the diversity of tastes in respect of the environment.

- The "Ark of Taste", an international project created in 1996 in Turin aimed at saving from extinction local and regional foods and supporting their producers.

- Slow Food "Presidia", which are considered the executive level of the "Ark of Taste" project (explained in more detail below).

The Slow Food Presidia project was founded to safeguard typical and traditional food production through the identification and public recognition of foods, linked to territorial identities, that are in danger of extinction [61]. Initially focused on Italian destinations, Slow Food now counts more than 400 Presidia across more than 50 countries aiming at protecting good, clean and fair products. The process of selection of these products is structured on several criteria: taste (as the product must be of high quality); history/culture/relationship with the territory (as the product must be linked to the memory and identity of a particular group or region); production scale (as the product must be realized in low quantities and from small firms); real or potential extinction risk, and the environmental and social sustainability of the product. Of the more than 400 Presidia, 269 are in Europe with 224 in Italy; each of the Presidia collects from three to 70 producers. Each Presidia focusses on particular topics such as agriculture and farming. Within each Presidia, a central role is played by the chefs who create the cuisines (and who have a specific network named "Alleanza tra i cuochi italiani con i Presidi Slow Food"). European Presidia are classified by typology in Table 1 and territorial distribution in Table 2 [60].

Table 1. Slow Food "Presidia" classified for typology

\begin{tabular}{ll}
\hline Typology & N. of "presidia" \\
\hline Coffee, cacao & 1 \\
Cereals and flours & 8 \\
Fruits and derivates & 27 \\
Milk and cheeses & 59 \\
Legumes & 20 \\
Honey & 1 \\
Oil & 1 \\
Vegetables and vegetable conserves & 34 \\
Pain, Sweets and oven products & 14 \\
Fish & 17 \\
Animal races and farmer & 39 \\
Salt & 2 \\
Salamis and derivates & 35 \\
Spices, herbs and spontaneous products & 4 \\
Wine and alcoholic drinks & 7 \\
Total & 269 \\
\hline
\end{tabular}

Source: Peano and Sottile, 2012.

Table 2. Slow Food "Presidia" classified for territorial distribution

\begin{tabular}{llll}
\hline Country & N. of presidia" & Country & N. of presidia \\
\hline Armenia & 1 & Macedonia & 2 \\
Austria & 5 & Italia & 201 \\
Bosnia & 2 & Netherlands & 8 \\
Herzegovina & & Poland & 2 \\
Belorussia & 1 & Portugal & 1 \\
Bulgaria & 3 & United Kingdom & 5 \\
Cyprus & 1 & Romania & 2 \\
Croatia & 1 & Spain & 9 \\
France & 15 & Switzerland & 3 \\
Georgia & 1 & Hungary & 1 \\
Germany & 4 & Total & 269 \\
Ireland & 1 & & \\
\hline
\end{tabular}

Source: Peano and Sottile, 2012.

Research conducted by Slow Food in 2012 shows how, on the basis of a sample of 46 Presidia, the level of sustainability measured on three scales (socio-cultural, food and economic) has improved in every case from their inception. With reference to the socio-cultural dimension, their research showed the importance of the relationships developed within the Presidia that became like virtuous circles of different people aimed at protecting and improving their products. Slow Food, in this regard, plays a very important role in connecting different people with each other. A meaningful element in the success of Presidia is also the presence of a local leader who develops a local project, as well as the presence of young people in the local Slow Food organization. Slow Food Presidia represent an alternative model of traditional production by small producers that anchor quality food products to their region and culture of origin [62]. 


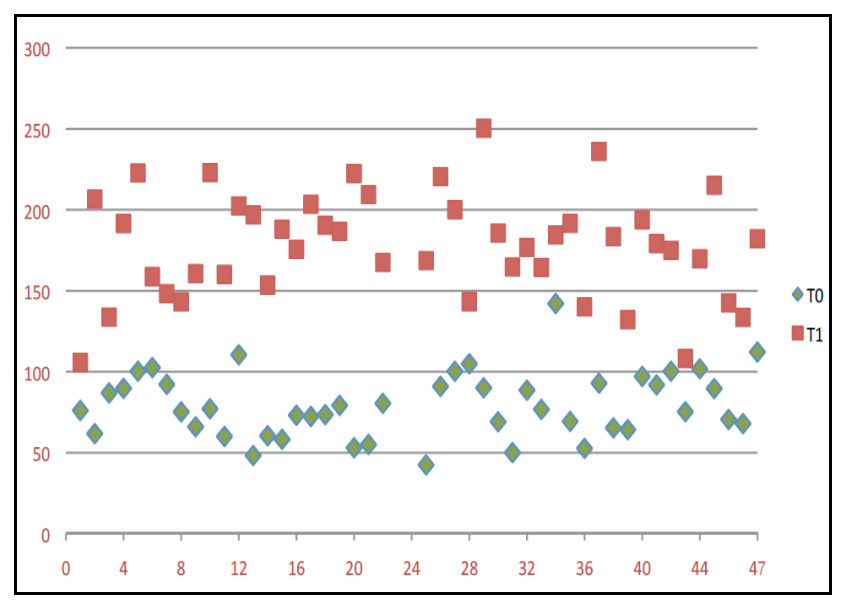

Source: Peano and Sottile, 2012.

Fig. 1. Sustainability analysis of 47 Slow Food "Presidia

In addition to the Presidia, as stated earlier, Slow Food is organized into approximately 1,500 chapters or "Convivia" across the globe. Each Convivia organizes a number of events each year. Even if the Convivia, and the related Cittaslow movements (developed in conjunction with Slow Food to ease the pace of urban life), are not directly aimed at tourism, they do influence local tourism by contributing to destination development. In addition, the Slow Food brand attached to Convivia events adds a layer of quality to the reputation of the event.

The "slow philosophy" has also led to the concept of Slow Tourism which encompasses travel and tourism activities that follow two essential principles: taking time, and attachment to a particular place. Slow Tourism emphasizes an engagement with place, encouraging tourists to establish local routines, try local food and appreciate local culture. Thus, Slow Tourism promotes "slow" lifestyle practices connected to the overall social movement.

The Slow Tourism label is able to attract tourists [63] towards international events (Slow Food website) including:

- "AsiO Gusto", the biennial celebration of the food traditions of Asia and Oceania.

- "Cheese", dedicated to milk in all its forms and cheese, held every two years in Bra, Italy.

- "Eurogusto", a celebration of European food and culture, held every two years in Tours, France.

- "Indigenous Terra Madre", a meeting of representatives of indigenous communities and food producers from around the world, held in Sweden in 2011.

- "Salone del Gusto" and "Terra Madre", the global meeting of the Slow Food and the Terra Madre network held in Turin, Italy.

- "Slow Fish", an event dedicated to sustainable and artisanal fishing, held every two years in Genoa, Italy.

- "Terra Madre Day", a celebration of local food held every year on 10 December [64]. The Terra Madre network also organizes many local and regional meetings.

In general terms, destinations have for some time utilized their local cuisine and gastronomic products as a source of tourist attraction [65]. But these specific events listed above are attractors for slow tourists. Salone del Gusto attracts over 150,000 visitors to Turin every two years, while Cheese attracts over 100,000 in a the small town of Bra [66]. Terra Madre involves about 5,000 persons representing different food communities. Indeed, the 2010 offering of Terra Madre and Salone del Gusto attracted more than 200,000 people and over 5,000 representatives of the global network from 160 countries [67], celebrating the crucial role played by local communities in fostering sustainable methods of food production and consumption [68, 69].

In this manner, the Slow Food movement participates in international markets and fairs to promote regional products at a global level, but also to promote traditional food in its own country. The development of gastronomic tourism represents one of the existing possibilities for rural areas to transition successfully to the new reality of a market-based economy [70]. This has the effect of increasing tourist arrivals to a region because of the specific products for which it becomes known [71]. The risk of this movement is that it may be an attractor of only a niche class while in reality it needs to find a way to attract a wider consumer base [72].

Slow Food can be considered a lifestyle reinvention approach which at the same time, due to its ethical food credentials, is an important attractor for tourists. This may occur through its influence on destination development. In addition, its brand equity may increase the perception of the quality of a region [63].

\section{Concluding Remarks}

Integrating ideas from ethical behavior, destination management and strategies for tourism development, this paper emphasizes the important role that ethical food could have in the future in destination attractiveness, contributing as well to the sustainability of a destination. The case of Slow Food shows that the association of a common philosophy and ethical background with the concept of eco-tourism can lead to tourism development, especially when linked to rural areas. With the development of gastronomic tourism, the value of the tourism product could be raised [70]. As maintained by Redl [5], local food and beverages are considered an important part of the travel experience and an important part of a country's culture. At the same time, gastronomic tourism allows for the preservation of local production, and advances the attractiveness and sustainability of the destination. As demonstrated by the case of Slow Food, building on cultural heritage through gastronomy can be a very important part of tourism development [6].

Given the limited number of studies on the impact of ethical food on tourism, there are significant gaps in the literature with respect to this field of study. This paper is an initial attempt to illustrate, through a real case study, the importance of ethical food in the attractiveness of destinations, and in tourism development. This study is conceptual only, and further empirical analysis is necessary to confirm the assertions made. Further, a comparison between different 
successful and unsuccessful ethical food tourism case studies may bring important results.

Another limitation of the paper is its focus specifically on an Italian case study. While Slow Food has obvious affiliates in other countries, some caution should be exercised in how far the conclusions can be extended. Further research might extend this paper's findings through an empirical analysis of the effect of ethical food destination image on tourist destination attractiveness.

Finally, a qualitative analysis based on interviews of stakeholders in this sector could result in important developments for ethical food marketing and ethical food tourism.

Given the impact that ethical food could have on the tourist industry, several strategies could be developed by different stakeholders for further development and growth.

Governments and local bodies should support the consumption and production of ethical food, thus driving prices down as consumption increases. At the same time, it is important to remember the need for appropriate pricing, to ensure animal welfare, environmental respect, and a salary sufficient to provide a living wage for the producer [52].

Further, it is only through education in ethical values that it may be possible to achieve long term behavior change; this can be realized by a structured educational program, including the development of research, information interpretation and decision making skills [73].

Producers could also diversify their product range in order to respect and accommodate the cultural diversity of food choices. It is consequently important to improve the level of transparency for the customer so that they can understand the provenance of the products they are buying. In addition, there is a need for marketers to create alternative ways of presenting value and costs, changing the way businesses define value in the economic exchange system [74]. Efforts could also be made in terms of promotion of various attributes of ethical food and in building trust in this food category; this could ensure the increased development of the ethical food market. FAO in 2001 outlined several important objectives to pursue in this direction: the creation of suitable mechanisms to balance competing market interests and solve conflicts; the promotion of the use of science and technology for a more equitable food system; the development of ethical codes of conduct able to guide food production systems where they don't exist; the encouragement of broad stakeholder participation in food policies, programs and projects; the promotion of transparency and public scrutiny in decision-making procedures in international food policy, and the periodic review of ethical commitments [75].

Food and logistics industries should also aim at a higher level of "sustainable distribution" so as to cover more than carbon emissions. In particular, businesses could supply an explanation of the way their distribution models contribute to addressing the social and cultural concerns expressed through the notion of food miles. This may be done by promoting local distinctiveness and diversity through the sharing of services and overheads with local operators [6].
In 2011, the Food Ethics Council stressed the importance of working with smallholders, who remain the majority of farmers worldwide, in order to gain the volumes they require to develop new forms of supply chain [76]. In this regard, a further strategy could consist of creating a sustainable supply chain able to align the incentives of all supply chain players. This would require open and cooperative relationships among the players [77, 78].

In addition to the previous proposals, it is necessary to achieve a higher level of flexibility in policy implementation when it comes to the effect of agriculture on the environment as well as the impact of rural development on upstream and downstream industries [17]. Furthermore, some form of taxation on unhealthy food stuffs (such as saturated fats, sugar and salt) could be an important step toward the diffusion of ethical food.

Finally, new solutions could be developed for the packaging of ethical food. The development of active packaging that provides recyclable, lightweight and biodegradable products should be encouraged. Technology may be harnessed for a more sustainable food supply chain, able to eliminate wasted space, increase shipping capacity, and reduce inbound shipping costs and greenhouse gas emission during transport and production (CDF Corporation).

Overcoming all these limitations would constitute an important step for ethical food tourism and allow, at the same time, a particular destination to be more attractive for a wide range of tourists.

\section{References}

[1] UNWTO, Global Report On Food Tourism. Madrid, Spain: UNWTO, 2012.

[2] Context Marketing, Ethical Food. Context Marketing, 2010.

[3] P. Sarkar (2014) Ethicurean- A Study on ethical Food Trends, Opportunities and Risks, in Advances in Hotel, Travel and Tourism Research: A Global Perspective, Babarasidas Chandiwala Institute of Hotel Management and Catering Technology, New Delhi, pp. 93-102.

[4] M. Clarke, Ethical Foods. International Situation Assessment, Opportunities and Threats. Barton: RIRDC, 2012

[5] S. Redl, Culinary Tourism for Young Adult Travellers and its connection to Destination Management, Bachelor Thesis, Vienna: Modul Vienna University, 2013.

[6] Food Ethics Council, Food Distribution. An Ethical Agenda. Brighton, UK: Food Ethics Council, 2008.

[7] M. Fischer Boel, “Just desserts': Ethics, Quality and Traceability in EU Agricultural and Food Policy" in Ethical Traceability and Communicating Food, C. Coff, D. Barling, M. Korthals, T. Nielsen, Eds. Dordrecht NL: Springer, 2008, pp. 260-263

[8] R. Sebastiani, F. Montagnini, and D. Dalli, "Ethical consumption and new business models in the food industry, evidence from the Eataly case",. Journal of Business Ethics, Vol. 14, No. 3, 2012, pp. 473-488 
[9] B. Huybrechts, and D. Reed, "Introduction: Fair trade in different national contexts", Journal of Business Ethics, Vol. 92, No. 2, 147-150.

[10] J.A. Muncy, and S.J. Vitell "Consumer ethics: An empirical investigation of the ethical beliefs of the final consumer", Journal of Business Research, Vol. 24, No.1, 1992, pp. 297-312.

[11] A. Crane, and D. Matten, Business Ethics. Oxford: OUP, 2004.

[12] W. Sinnott-Armstrong, "It's Not My Fault", in Advances in the economics of environmental resources: Vol. 5. Perspectives on Climate Change. Science, Economics, Politics, Ethics, W. Sinnott, Armstrong, and R. B. Howarth, Eds. Amsterdam, Elsevier, 2005, pp. 285-307.

[13] I. Szmigin, and M. Carrigan, "Exploring the dimensions of ethical consumption", European Advances in Consumer Research, Vol. 7, 2006, pp.608-613.

[14] D. B. Holt, "How consumers Consume: A Typology of consumption practices", Journal of Consumer Research, Vol. 22, No. June, 1995, pp. 1-16.

[15] J. Snider, R.H. Paul, and D. Martin, "Corporate social responsibility in the 21st century: A view from the world's most successful firms", Journal of Business Ethics, Vol. 48, No. 2, 2003, pp. 175-187.

[16] M. Grimmer, and T. Bingham "Company environmental performance and consumer purchase intentions", Journal of Business Research, Vol. 66, 2013, pp. 1945-1953.

[17] OECD, The Future of Food. Long-term Prospects for the Agro-food Sector. Paris: OECD, 1998.

[18] H. Willer, and L. Kilcher, The World of Organic Agriculture Statistics and Emerging Trends 2011, FIBL-IFOAM Report, Bonn, Germany: IFOAM, 2011.

[19] E. Tavella, and C.N. Hjortso, "Design and manage local organic food supply chains: benefits of using soft systems methodology", 2011, Online available from http://journals.isss.org/index.php/proceedings55th/article/view File/1629/603 (Accessed 18 November 2014).

[20] S. Balu, N. Garg, P. Majumder, J. Park, R. Sawani, and D. Sharma, "Ethical food consumption: a discussion on the environmental and social impacts of "green foods"', MBA White Paper, UNC Kenan-Flagler Business School, W06-021, 2006, pp. 1-6.

[21] H. Buller, and C. Morris, Farm animal welfare aspects of the CAP. London: RSPCA, 2002.

[22] Welfare Quality, "Science and society improving animal welfare", Welfare Quality conference proceedings, Brussels, Belgium, pp. 1-8, 2005.

[23] H. Buller, and C. Morris, "Farm animal welfare: a new repertoire of nature-society relations or modernisms re-embedded?", Sociologia Ruralis, Vol. 43, No. 3, 2003, pp. 216-237

[24] D.E. Goodman, "Agro-Food Studies in the 'Age of Ecology': Nature, corporeality, bio-politics", Sociologia Ruralis, Vol 39, No. 1, 1999, pp. 17-38.

[25] L. Busch, "The moral economy of grades and standards", Journal of Rural Studies, Vol. 16, No. 3, 2000, pp. 273-283.

[26] http://www.ft.com/cms/s/0/236d978c-bbac-11e1-9436-00144f
eabdc0.html\#axzz25Col1UXR

[27] E. Papaoikonomou, G. Ryan, and M. Ginieis, "Towards a holistic approach of the attitude behaviour gap in ethical consumer behaviours: empirical evidence from Spain", Int. Adv. Econ. Res., Vol. 17, No. 1, 2011, pp.77-88.

[28] IGD, Ethical Shopping in Europe, Radlett, Herts: IGD, 2008.

[29] J. Sánchez-Taylor, J., "Sex tourism and inequalities" in Tourism and Inequality: Problems and Prospects, S. Cole, and N. Morgan, Eds. Wallingford, Oxfordshire: CAB International, 2010, pp. 49-66.

[30] S. Carlisle, "Access and Marginalization in a Beach Enclave Resort" in Tourism and Inequality: Problems and Prospects, S. Cole, and N. Morgan, Eds. Wallingford, Oxfordshire: CAB International, 2010, pp. 67-84.

[31] S. Cole, and N. Morgan, Tourism and Inequality: Problems and Prospects. Wallingford, Oxfordshire: CAB International, 2010.

[32] C.M. Hall, "Equal access for all? regulative mechanisms, inequality and tourism mobility", in Tourism and Inequality: Problems and Prospects, S. Cole, and N. Morgan, Eds. Wallingford, Oxfordshire: CAB International, 2010, pp. 34-48.

[33] K.L. Andereck, M.V. Karin, R.C. Knopf, and C.A. Vogt, "Residents' perceptions of community tourism impacts", Annals of Tourism Research, Vol. 32, No. 4, 2005, pp. 1056-1076.

[34] C. Choi, and I. Murray, "Resident attitudes toward sustainable community tourism", Journal of Sustainable Tourism, Vol. 18, No. 4, 2010, pp. 575-594.

[35] M. Grimmer, M. Cugno, and M. Viassone, "Vecchie e nuove prospettive di sviluppo del turismo in Italia", Rassegna Economica, Vol. 1, 2012, pp. 45-73.

[36] C. Bender, "Thinking globally, acting locally, discussing online: The slow food movement quickens with new media", Communication Theses. Paper 86, 2012.

[37] C.M. Hall, L. Sharple, R. Mitchell, and N. Macionis, Food Tourism around the World. Development, Management and Markets. Abingdon, Oxon: Butterworth-Heinemann, 2003.

[38] S. Vengesayi S, "Destination attractiveness: Are there relationships with destination attributes", The Business Review, Cambridge, Vol. 10, No. 2, pp. 289-294.

[39] M. Trunfio, L. Petruzzellis, and C. Nigro, "Tour operators and alternative tourism in Italy: Exploiting niche markets to increase international competitiveness", International Journal of Contemporary Hospitality Management, Vol. 18, No. 5, 2006, pp. 426-438.

[40] D. Alexander, "The geography of Italian pasta", The Professional Geographer, Vol. 52, No. 3, 2000, pp. 553-566.

[41] C.M. Hall, and L. Sharples, "The consumption of experiences or the experiences of consumption? An introduction to the tourism of taste", in Food Tourism Around the World: Development, Management and Markets, C. M. Hall, E. Sharples, R. Mitchell, N. Macionis, and B. Cambourne, Eds. Oxford: Butterworth-Heinemann, 2003, pp. 1-24.

[42] C.M. Hall, E. Sharples,R. Mitchell, B. Cambourne, and N. Macionis, Food Tourism Around the World: Development, Management and Markets. Oxford: Butterworth-Heinemann, 2003. 
[43] FAO, Ethical Issues in Food and Agriculture. Rome: FAO.

[44] D. Birch, Understanding Drivers and Barriers to Consumption of South East Queensland Local and Regional Foods. Maroochydore: Queensland Government, 2012.

[45] SERIO, Research \& Innovation. 2008. Understanding of Consumer Attitudes and Actual Purchasing Behaviour, with Reference to Local and Regional Foods, Plymouth, Devon: University of Plymouth, Drake Circus, 2008.

[46] J. Sweney, "Slow Food. Enriching the Tourism experience through agricultural diversity", Tourism and Hospitality Research in Ireland. Concepts, Issues and challenges, THRC Waterford Institute of Technology. School of Humanities publications, 2007.

[47] Almatourism, Food between Tourism and Life Quality, https://blogeirest.files.wordpress.com/2014/01/almatourism-ca 11.pdf

[48] T. Lang, "From 'value-for-money' to 'values-for-money'? Ethical food and policy in Europe", Environment and Planning A, Vol. 42, No. 8, pp. 1814-1832.

[49] C. Strauch, and B. Schaer, Netzwerke für Kommunikation und Kooperation in den Produktmärkten Bio-Fleisch und Bio-Getreide, Freising: Ecozept GbR, 2005.

[50] http://ec.europa.eu/research/participants/data/ref/fp7/89847/re search-food_en.pdf

[51] J.N. Pretty, A.S. Ball, T. Lang,. and J.I.L. Morison, "Farm costs and food miles: An assessment of the full cost of the UK weekly food basket", Food Policy, Vol. 30, No. 1, 2005, pp. $1-19$.

[52] http://www.wordwendang.com/en/word_economy/0617/4953 7 2.html

[53] S. Żakowska-Biemans, "Factors underlying consumption of organic food in the opinion of Polish consumers", Agronomy Research, Vol. 7, Special issue II, 2009, pp. 768-774.

[54] W. Young, K. Hwang, S., McDonald,. and C.J. Oates, "Sustainable consumption: green consumer behaviour when purchasing products", Sustainable Development, Vol. 18, No. 1, 2010, pp. 20-31.

[55] http://www.ethicalconsumer.org/commentanalysis/consumeris $\mathrm{m} /$ thepriceofethics.aspx

[56] C. Petrini, and G. Padovani, Slow Food Revolution. Milano: Rizzoli, 2005.

[57] C. Petrini, Buono, Pulito e Giusto. Turin: Einaudi, 2005.

[58] M. Fonte, "Slow Food's presidia: what do small producers do with big retailers?", in Between the Local and the Global (Research in Rural Sociology and Development, Volume 12) T. Marsden, and J. Murdoch, Eds. Bingley, UK: Emerald Group Publishing Limited, 2006, pp.203 - 240

[59] S. Buiatti, "Food and tourism: the role of the 'Slow Food' Association"”, in Food Agri-culture and Tourism, K. Sidali, A. Spiller, and B. Schulze, Eds. 2011, Heidelberg, Springer.

[60] http://www.academia.edu/896364/SLOW_FOOD_Enriching_t he_Tourism_experience_through_agricultural_diversity

[61] E. Lorenzini, “Origin labelled products, territorial marks and their contribution to rural development. Evidence from Italy and France”, Working Paper SIEP, No. 649, 2010.

[62] C. Peano, and F. Sottile, Slow Food Presidia in Europe: A Model of Sustainability. Bra, Slow Food Foundation for Biodiversity, Accessible on: http://www.slowfood.com/sloweurope/wp-content/uploads/Ri cerca-presidi-Europa-ENG.pdf .

[63] H.R. Yurtseven, and O. Kaya, "Slow tourists: a comparative research based on cittaslow principles", American International Journal of Contemporary Research, Vol.1, No. 2, 2011, pp. 91-98.

[64] http://www.slowfood.com/international/21/our-events

[65] A. H.N. Mak, M. L., and A. Eves, Globalisation and food consumption in tourism, Annals of Tourism Research, Vol. 29, No.1, 2012, pp. 171-196.

[66] S. Fullagar, K. Markwell, and E. Wilson, Slow Tourism: Experiences andMobilities. Bristo: Channel View, 2012.

[67] Salone Internazionale del Gusto (2011). http://www.salonedelgusto.com/. Accessed December 14, 2011.

[68] Terra Madre (2011) http://www.terramadre.info/pagine/welcome.lasso?n=en\&-ses sion=terramadre:6D711C1E02a9e20041uXV32A86DC. Accessed December 14, 2011.

[69] A. Tencati, and L. Tsolnai, "Collaborative enterprise and sustainability: the case of Slow Food", Journal of Business Ethics, Vol. 110, No. 3, 2012, pp. 345-354.

[70] M. Bratec, "Sustaining through Gastronomy: The Case of Slow Food Movement in Slovenia, its Impacts on Socio-cultural Environments and Tourism Development”, BEST Education Network Think Tank VIII Sustaining Quality of Life through Tourism, 2008.

[71] M.C. Muntean, C. Nistor, R. Nistor, D. Sarpe, "OENO-Gourmet Tourism - A new way of Romanian tourism boost", Latest Trends on Cultural Heritage and Tourism, 2010, 241-246.

[72] C. Petrini, B. Watson, and D. Madison, Slow Food: Collected Thoughts on Taste, Tradition, and the Honest Pleasures of Food. Bra: Slow Food Editore, 2001.

[73] A. Dobson, "Environmental citizenship: towards sustainable development", Sustainable Development, Vol. 15, No. 5, 2007, pp.276-285.

[74] M.J. Polonsky, “Transformative green marketing: Impediments and opportunities", Journal of Business Research, Vol. 64, No. 12, 2011, pp. 1311-1319.

[75] FAO, Report of the Panel of Eminent Experts on Ethics in Food and Agriculture. Rome: Editorial Group FAO Information Division, 2001.

[76] Food Ethics Council, The Future of Food. Foresight and beyond. Brighton: Food Ethics Council, 2011.

[77] N. Dolšak, and E. Ostrom, The Commons in the New Millennium: Challenges and Adaptation. Cambridge, MA: MIT Press, 2003.

[78] Sustainability Institute, Commodity System Challenges: Moving Sustainability into the Mainstream of Natural Resource Economies. Hartland: Sustainability Institute, 2003. 